\title{
Sister city bottom up collaborative model plan as a major flooding mitigation in Samarinda
}

\author{
Muhammad Najeri Al Syahrin'1, Gilang Mukti Rukmana², Dzul Rachman³, Ahmad \\ Harakan $^{4}$ and Farida Tadjine ${ }^{5}$ \\ ${ }^{1,2,3}$ Universitas Muhammadiyah Kalimantan Timur, Indonesia \\ ${ }^{4}$ Universitas Muhammadiyah Makassar, Indonesia \\ ${ }^{5}$ University of Kasdi Merbah Ouargla, Algeria \\ \{gmukti.rukmana@gmail.com ${ }^{2}$ \}
}

\begin{abstract}
Flooding is a big homework for the City Government of Samarinda. Flood problems in Samarinda often occur when the rainfall is high even though the duration of the rain is relatively short. This article aims to analyze the sister city cooperation framework model that can be carried out by the city government of Samarinda in dealing with flood problems. The research question in this study is how to design an effective sister city cooperation model and can be used as an attempt to resolve flood problems in Samarinda City. The data collection process in this study used qualitative methods with a literature study approach and interviews with community leaders. The cooperative system framework of the bottom-up model is designed based on the complex interdependence theory by Joseph Nye and Robert Keohane, the authors argued that the collaboration between the Samarinda City Government and transnational actors, supported by active participation from local communities, can be a good collaboration in creating effective solutions related to flood mitigation in Samarinda. The author found that the involvement of the community through socialization and education about the importance of maintaining river ecosystems, mutual cooperation activities in the form of cleaning waterways and drainage, and structuring and relocating residential areas located on the riverbanks, are aspects that play important roles in the process of resolve flood Samarinda City.
\end{abstract}

Keywords: Flooding, sister city, ecosystem, river

\section{INTRODUCTION}

International changes due to globalization have caused a shift in the implementation of relations between government and the state. The advancement of communication technology has also encouraged interdependence not only for the state but also groups within the country including local authorities [1]. The phenomenon has enabled the local authorities to become interested in cooperation with local authorities in other countries to make profits for both areas which participated in the program. The form of bilateral cooperation that is currently being carried out is the sister city cooperation model (city partners). Sister city cooperation is a form 
of cooperation involving cities in one country with cities in other countries to increase the sense of inter-city brotherhood and benefit both parties [2].

As the capital of East Kalimantan province, Samarinda currently still has a major problem, namely flooding. Understanding disasters that are based on universal balance, there is an understanding based on environmental balance. We cannot deny that humans live side by side and need each other through their interactions with nature. This interaction is very neat and systemic so that overall it runs very regularly [3].

Flood disasters will cause adverse impacts on various people's lives. In addition to material losses, the moral loss that arises is a mental condition that decreases or is disrupted due to loss of property by a flood [4]. Various efforts have been made, such as maintenance of city drainage channels, revamping of rivers that cross the city, various studies related to city flood control, construction of flood control facilities as well as several rules that have been issued for flood control, but these efforts were not optimal yet in overcoming flooding problems [5]. Therefore, a new framework in integrated flood management is needed through sister city cooperation.

The formation of sister city cooperation shows that every local authorities cannot always rely on its domestic potential to fulfill its needs, but it can be fulfilled by other countries through a cooperation scheme [6]. Sister city cooperation is important considering that besides involving various flood problem experts in the international world who are experienced in overcoming flooding in their countries, sister city cooperation also allows the transfer of technology in handling flood problems, so that it is expected through a mechanism of cooperation, flood problems in Samarinda can be resolved.

\section{METHODOLOGY}

Research on this sister city cooperation model used literature studies and interview methods to examine and understand how the sister city development model is good to be applied in Samarinda flood prevention. Qualitative research aims to explore and understand flood issues and provide an effective sister city cooperation model through community engagement in said problems. The interesting thing about this research is the creation of Samarinda city sister cooperation platform with the active involvement of the community in order to mitigate the flooding. Hopefully there are benefits gained for the citizen of Samarinda city through this collaboration.

The method that will be used in determining primary source data or an informant is purposive sampling through chosen sources. A chosen source is the person who has the capacity and capabilities according to the needs of the research. Data from the informant will add validity to the research that has been conducted. To facilitate the determination of the informant in the field, researcher targeted key informants from the local authorities of Samarinda city and community leaders in Temindung Village, Gunung Lingai Village, and Bengkuring area, the main areas affected by the biggest floods in Samarinda.

\section{RESULT AND DISCUSSION}

Samarinda which is an area prone to changes in natural conditions resulting in high intensity of flood disasters and poor city drainage, coupled by the increasing Mahakam river water discharge, is considered to be the main cause of floods in the city of Samarinda [5]. Although different from the capital city of Jakarta, which almost every year has a flood problem with the main cause a combination of two main factors which are global climate change and land subsidence [7]. 
In April 2017 there had been a disastrous flood, resulting in the city's disaster relief work (BPBD), the state of the city, set the status of one. The data from the tempo also shows that 10,000 homes were affected by the flood and resulted in at least four in samarinda [8]. The flood in April 2017 was the biggest flood in Samarinda in the last 10 years since 2008 [9]. Looking at the condition, it requires a collaborative strategy in the process of settlement. Sister city's model of cooperation was then regarded as an alternative solution to support the government's efforts of Samarinda in the cover of a flood in Samarinda.

The modeling of sister city or twin cities is a model of cooperation between one city and another that is based on similarities like disaster, geographical, economic, social structures, cultural and other features that have the same thing that both cities have in common. This study is planning to build a model of sister city's research in the town of Samarinda in the East Kalimantan province. Therefore we are managing director of research. The plan is to take this town into a state of collaboration with sister city, assuming that the problem will be taken care of by the state's government.

\subsection{Community Involvement in Flooding Mitigation in Samarinda}

In this study the authors involved communities in the region who were affected by the flood to participate in the implementation of the sister city research. The sister city cooperation model research in Kota Samarinda has been conducted by contacting several related parties such as the city government Samarinda, kelurahan, and the community as actors in implementing sister cities, and conducting field surveys related to the area that will be used as implementation of sister city cooperation, namely in Sempaja Timur Village, Gunung Lingai, and Temindung Permai. These three areas are the research sites of the sister city model collaboration in Samarinda city with active involvement of the community.

In fact, local people have taken a flood prevention effort by running a monthly program like a month of service in a month to get together cleaning up the blocked sewer in the area. Next, Gunung Lingai Village is also one of the areas most vulnerable to flooding. According to Siswo as the Head of Mount Lingai Urban Village, there are actually efforts that can be made to prevent the potential flooding that occurs in the Mount Lingai area, namely by running mutual cooperation that has been held regularly every week and relocating residents' homes in the river area.

The third area which is the object of research because it is known as a flood-prone area is located in the Temindung Permai area. Temindung Permai Village is one of the villages in Sungai Pinang Subdistrict, with an area of approximately 130.56 Hectares. The river of concern to the flood in the Temindung area is the Karang Mumus River, where the river is the Mahakam River Basin in Samarinda.

In general, the three villages have a different concept of community involvement, the difference is based on the characteristics of the community and the different causes of flood problems faced by each village in the city of Samarinda. In general, from the three villages, three aspects of community involvement can be identified in Samarinda city flood mitigation.

In Temindung village, the community is actively involved through education about the importance of maintaining river ecosystems and disseminating local wisdom so that the community can overcome the problem of flooding. In Sempaja Timur Village, active involvement of the community is manifested in the form of mutual cooperation in cleaning the water and drainage channels. While in the Gunung Lingai village, active community involvement can be tangible to the arrangement and relocation of housing and riverbank settlements. Arrangement of residents' settlements around the river banks is considered a crucial problem in handling flooding in Gunung Lingai Village. 


\subsection{Sister City Bottom Up Collaborative Model Plan as a major flooding mitigation in Samarinda}

In sister city cooperation, a bottom up model conducted between cities between countries in handling floods involves the community in the formulation and implementation of agreements. These activities include floodplain management, mapping of flood-prone areas per RT per village, flood forecasts and early warnings, settlement relocation, spatial improvement and reforestation, watershed erosion reforestation, river boundary determination, public information delivery and solid waste information and management [10].

Cooperation with sister city bottom up began by identifying flood problems in the area of the city of Samarinda as well as a comprehensive review of the flood strategies in the society's perspective. Later, the city of Samarinda initiated an activity program that would encourage communities to interfere with the policies implemented by the government in efforts to cope with the flood. Bottom in the framework of sister city viewing the policy process as a negotiation and the forming of consensus. This model is carried out collectively and involves elements of governance that rely on persuasion approaches. The main arguments of sister city are bottom up are covering various aspects as follows, 1) looking at performance and effectiveness; (2) focusing on social virtues or local wisdom; (3) it is substantially more micro to the wider area (people to the government); (4) tend to be street-oriented, responsive, and short-term; (5) carrying a local micro-substance; (6) people, the private parties, and NGO as the primary objects in sister city's cooperation program approach.

\section{CONCLUSION}

The working model of sister city bottom up was based on the problems of the flood as a major problem in the city of Samarinda. This cooperation is an effort to involve all parties especially in society so that every decision taken in planning is a collective decision, and encourages participation and commitment to enforce it. While there are some weaknesses in the model it takes a lot of time and energy in the planning, but the results expected in the program's implementation can be more effective in the flood treatment.

The point of equal success is responsibility, decisions, and real action when disasters occur and how evacuation is carried out. This whole cooperation has been a collective dependency of the city (municipality) and residents (resident). The managing of this model of collaboration lies in the efforts of the city and its citizens. The city's government is acting as a provider in doing surveillance of areas of the flood and providing construction to people. The city's government is also the same as being employed by volunteers and NGO in contributing to the good benefits of funding and community service. The public is also tried to be always trained in preventive preventive efforts in situations where itis critical to provide a favorable response when an emergency occurs. Preparedness, the resilience and active participation of society is crucial to the face of a flood. The result can be understood because people are part of the victims of disaster, resulting in a high spirit and motivation to act and to strive for the disaster they face in their territory.

\section{References}

[1] Buckley P Takahashi A Anderson A Buckley P H Takahashi A and Anderson A, Jun. 2015 The Role of Sister Cities' Staff Exchanges in Developing "Learning Cities": Exploring Necessary and Sufficient Conditions in Social Capital Development Utilizing Proportional Odds Modeling Int. J. Environ. Res. Public Health 12, 7 p. 7133-7153. 
[2] Ogawa A, 2012, Sister City as Preservation Strategy, Columbia University.

[3] Awalia V R Mappamiring M and Aksa A N, Oct. 2015 PERAN PEMERINTAH DALAM MENANGGULANGI RESIKO BENCANA BANJIR DI KABUPATEN KOLAKA UTARA Otoritas J. Ilmu Pemerintah. 5, 2.

[4] Nasyiruddin N Muhammadiah $M$ and Badjido M Y, Oct. 2015 STRATEGI PEMERINTAH DAERAH DALAM PENANGGULANGAN BENCANA BANJIR DI KABUPATEN BANTAENG Otoritas J. Ilmu Pemerintah. 5, 2.

[5] Rafiq A Idris A and Sugandi S, 2014 Studi Tentang Program Kebencanaan Dalam Samarinda Pada Badan Penanggulangan Bencana Daerah (BPBD) Provinsi Kalimantan Timur eJournal Adm. Reform 2, 3.

[6] Fitriyah H R and Rani F, Jan. 2014 Implementasi Kerjasama Sister City Studi Kasus Sister City Bandung - Braunschweig (Tahun 2000 - 2013) Transnasional 5, 01 p. 922 935.

[7] Widodo A, Dec. 2017 Analyzing Indonesia's NCICD Project to Stop the Capital City Sinking Otoritas J. Ilmu Pemerintah. 7, 2 p. 54-66.

[8] Maulana S, Apr-2017, Banjir Landa 4 Kelurahan di Samarinda, 10.000 Rumah Terendam, Tempo.co, Jakarta.

[9] Christoper D, Apr-2017, Banjir Besar di Samarinda Siklus 10 Tahunan, Tribunnews.com. .

[10] Gusti G, 2013, Pakar UGM Beri Masukan Mengatasi Banjir Jakarta, Ugm.ac.id. . 